\title{
PENYELESAIAN SENGKETA ALTERNATIF PADA SENGKETA KONSUMEN
}

\author{
Oleh :
}

\section{AriPurwadi}

\begin{abstract}
Settling customer dispute can be done using out of court dispute settlement in conciliaation, mediation, and arbitration ways. Initial step in settling the customer dispute done using negotiation model. The prosess of out of court dispute settlement utilizes alternative dipute resolution for civil responsibility aspect.
\end{abstract}

Key words: Customer Dispute, Civil Responsibility, Out of Court Dispute Settlement, Alternative Dispute Resolution.

\section{PENDAHULUAN}

Sengketa konsumen adalah sengketa berkenaan dengan pelanggaran hak-hak konsumen. Penggunaan istilah "sengketa konsumen" ini memberikan ruang lingkup lebih luas daripada istilah "sengketa transaksi konsumen". Hal ini disebabkan istilah "sengketa transaksi konsumen" hanya mencakup aspek hukum keperdataan, sedangkan istilah "sengketa konsumen" meliputi baik aspek hukum keperdataan, maupun aspek hukum pidana serta aspek hukum administrasi (Sidharta, 2000 : 135).

Pelanggaran hak-hak konsumen merupakan persoalan hukum, sehingga penyelesaiannya merupakan penyelesaian hukum, yaitu melalui badan peradilan. Pada pelanggaran hak-hak konsumen tentu bisa menimbulkan tuntutan hak. Tuntutan hak yang dilakukan konsumen pada dasarnya berfungsi :

1. Untuk memulihkan hak-hak konsumen yang dilanggar.

2. Dosen Fakultas Hukum Universitas Wijaya Kusuma Surabaya

3. Untuk memulihkan atas kerugian baik materiil maupun immaterial yang telah diderita konsumen, dan

4. Untuk memulihkan dalam keadaan semula (Purwadi, 2001 : 255).

Sebenarnya penyelesaian sengketa konsumen itu dilakukan dengan berbagai model penyelesaian sengketa konsumen. Model yang pertama dikenal dengan mekanisme penyelesaian sengketa konsumen secara sukarela. Melalui mekanisme ini, konsumen 
langsung menuntut haknya kepada pelaku usaha yang menyebabkan kerugian pada diri konsumen. Mekanisme penyelesaian sengketa konsumen dengan meminta ganti-rugi disebut penyelesaian sengketa di luar pengadilan. Model kedua yaitu dengan dibentuknya Small Claims Court. Model ini dilakukan di negara Inggris, Selandia Baru, negaranegara Skandinavia, Hongkong, dan beberapa negara bagian Amerika Serikat. Small Claims Court ini merupakan suatu sistem peradilan khusus untuk menangani tuntutan ganti-rugi atas kerugian dalam jumlah yang kecil. Peradilan ini merupakan suatu sistem peradilan yang benar-benar cepat, mudah, dan murah. Peradilan khusus semacam ini merupakan badan yang berdiri sendiri dan merupakan quasi judiciil atau bisa merupakan kamar tersendiri di pengadilan negeri (merupakan bagian dari peradilan umum).

Model ketiga, yaitu mekanisme penyelesaian sengketa konsumen melalui badan peradilan. Dalam hubungan ini, Az. Nasution juga menguraikan bentukbentuk penyelesaian sengketa, yaitu :

1. Cara-cara perdamaian,

2. Penyelesaian melalui instansi yang berwenang. yaitu:

a. mengadukan atau melaporkan gangguan kepentingan konsumen kepada instansi pemerintah atau instansi penegak hukum apabila ada unsur-unsur perbuatan pidana dan/atau b. mengajukan gugatan ganti-rugi kepada pengadilan (Nasution, 1995: 179).

Apabila kita berbicara mengenai hak konsumen dan kemudian timbul adanya pelanggaran hak konsumen, maka sebenarnya ada kepentingan konsumen yang harus dilindungi oleh hukum. Jadi hak konsumen itu bisa diartikan hukum mengalokasikan kekuasaan konsumen untuk bertindak dalam rangka kepentingan konsumen (bandingkan Rahardjo, 2000 :53).

Kepentingan konsumen itu meliputi 3 hal, yaitu :

1. Kepentingan fisik konsumen, artinya produk yang dikonsumsi itu tidak mengganggu keamanan dan keselamatan baik tubuh dan atau jiwa konsumen.

2. Kepentingan sosial ekonomi konsumen, yaitu dalam mendapatkan produk itu harus merupakan hasil optimal dari penggunaan sumber--sumber ekonomi konsumen untuk kebutuhan hidupnya.

3. Kepentingan hukum konsumen, yaitu adanya instrumen hukum perlindungan konsumen.

Kepentingan-kepentingan konsumen inilah yang oleh hukum dialokasikan kekuasaannya dalam bentuk hak-hak konsumen. Ada beberapa hak konsumen yang perlu diperhatikan dalam rangka perlindungan konsumen, yaitu hak untuk mendapatkan penyelesaian hukum dan hak untuk mendapatkan ganti kerugian. Jika konsumen merasakan kuantitas dan kualitas produk (barang dan/ atau jasa) yang dikonsumsi tidak sesuai dengan nilai 
tukar yang diberikannya, konsumen berhak mendapatkan ganti kerugian yang pantas. Konsumen juga berhak menuntut pertanggungjawaban hukum dari pihak-pihak yang dipandang merugikan karena mengkonsumsi produk tersebut. Hak untuk mendapatkan penyelesaian hukum ini sebenarnya meliputi juga hak untuk mendapatkan ganti kerugian tetapi kedua hak tersebut tidak berarti identik. Untuk memperoleh ganti-kerugian, konsumen tidak selalu harus menempuh upaya hukum terlebih dahulu.

Apabila hak untuk mendapatkan penyelesaian hukum ini dihubungkan oleh kepentingan hukum konsumen tentu mempertanya-kan : sejauh mana instrumen hukum perlindungan konsumen mengatur hak tersebut ? bagaimana model penyelesaian hukumnya ? Serta dengan cara bagaimana penyelesaian hukum dilakukan?

Instrumen hukum positif yang melindungi konsumen saat ini adalah Undang-Undang Nomor 8 Tahun 1999 Tentang Perlindungan Konsumen (untuk selanjutnya ditulis UUPK). UUPK ini merupakan "umbrella provision", artinya undang-undang yang mengintegrasikan dan memperkuat penegakan hukum di bidang perlindungan konsumen masih terbuka kemungkinan terbentuknya undang-undang baru yang bersifat sektoral yang memuat ketentuan yang melindungi konsumen. UUPK ini mengatur 8 (delapan) hak yang secara eksplisit dimuat dalam pasal 4 UUPK, sementara satu hak terakhir dirumuskan secara terbuka, yaitu : hak-hak yang diatur dalam ketentuan peraturan perundang--undangan yang lain.

Di samping itu, proses beracara dalam penyelesaian sengketa konsumen juga diatur dalam beberapa pasal dalam UUPK.

Dengan UUPK ini, pemerintah akan membentuk Badan Penyelesaian Sengketa Konsumen (BPSK) di daerah tingkat II. Dalam rangka pelaksanaan pasal 53 dan 54 UUPK ditetapkan Keputusan Menteri Perindustrian dan Perdagangan Nomor : 350/MPP/Kep/12/2001 tentang Pelaksanaan Tugas dan Wewenang Badan Penyelesaian Sengketa Konsumen. BPSK ini berfungsi untuk menangani dan menyelesaikan sengketa di luar pengadilan. Sedangkan untuk melaksanakan fungsi tersebut, maka salah satu tugas dan wewenang adalah BPSK melaksanakan penanganan dan penyelesaian sengketa konsumen dengan cara konsiliasi, mediasi, dan arbitrase.

Berdasarkan uraian tersebut di atas, maka tulisan ini mencoba untuk mengupas sejauhmana proses penyelesaian sengketa konsumen dilakukan melalui penyelesaian sengketa alternatif (alternative dispute resolution) serta betapa pentingnya penyelesaian sengketa konsumen dengan cara konsiliasi, mediasi dan arbitrase.

\section{PEMBAHASAN}

\section{Model Penyelesaian Sengketa Konsumen}

UUPK sama sekali tidak memberikan definisi atau pengertian mengenai "sengketa konsumen". 
Namun, istilah "sengketa konsumen" yang dijumpai dalam beberapa bagian UUPK, yaitu pada :

1. Penyebutan "sengketa konsumen" sebagai bagian dari institusi yang diintroduksikan oleh UUPK. yang bertugas menangani dan menyelesaikan sengketa antara pelaku usaha dan konsumen, yaitu Badan Penyelesaian Sengketa Konsumen (BPSK) (pasal 1 butir 11 UUPK jo Bab XI UUPK);

2. Penyebutan "sengketa konsumen" menyangkut tata cara penyelesaian sengketa pada Bab X Penyelesaian Sengketa, disebut secara konsisten pada pasal 45 ayat (2) dan 48 UUPK (Yusuf Shofie, 2003: 12).

Namun, dalam pasal 1 angka 8 Keputusan Menperindag Nomor : 350/MPP/Kep/12/2001 dengan tegas memberikan pengertian "sengketa konsumen" adalah sengketa antara pelaku usaha dengan konsumen yang menuntut ganti rugi atas kerusakan, pencemaran dan/atau menderita kerugian akibat mengkonsumsi barang dan/atau memanfaatkan jasa.

UUPK mengatur penyelesaian sengketa konsumen yaitu diatur dalam pasal 45 sampai dengan pasal 59. Sengketa konsumen ini memiliki 2 aspek, yaitu pertanggungjawaban perdata dan pertanggungjawaban pidana. Namun, kalau diperhatikan pengertian "sengketa konsumen" sebagaimana yang diatur dalam pasal 1 angka 8 Keputusan Menperindag Nomor : 350/MPP/Kep/
12/2001 lebih menekankan pada pertanggungjawaban perdata. Pada pasal tersebut ditekankan pada adanya hak untuk menuntut ganti-rugi.

Sedangkan manifestasi dari pertanggungjawaban perdata atau diistilahkan sebagai "tanggung gugat" (liability) ini, konsumen mempunyai hak mengajukan tuntutan ganti-rugi melalui suatu gugatan kepada pelaku usaha. Gugatan dilakukan terutama oleh konsumen yang dirugikan atau ahli waris yang bersangkutan. Hal ini disebabkan konsumen yang dirugikan adalah pihak yang mempunyai kepentingan akan perlindungan hukum, sehingga ia mengajukan tuntutan hak.

Namun, tidak semua kepentingan dapat diterima sebagai dasar pengajuan tuntutan hak, tetapi hanya kepentingan yang cukup dan layak, serta mempunyai dasar hukum sajalah yang dapat diterima sebagai dasar tuntutan hak. Para pihak dalam kedudukan sebagai pihak-pihak yang dapat diwariskan, sehingga ahli waris konsumen yang dirugikan dapat mengajukan tuntutan hak (gugatan).

Tuntutan hak yang berupa meminta ganti-rugi ini timbul karena adanya kerugian di pihak konsumen (lihat pasal 46 huruf a UUPK jo. pasal 15 Keputusan Menperindag Nomor : 350/MPP/Kep/12/2001). Kerugian itu, pada hakekatnya, adalah berkurangnya harta kekayaan seseorang akibat perbuatan melanggar hukum, sehingga tuntutan ganti-rugi tersebut dapat diwariskan. Sebenarnya, menurut Hukum Perdata (baca : sistem BW) dasar yang dapat 
digunakan untuk mengajukan tuntutan ganti-rugi itu ada 2 dasar, yaitu wanprestasi (ingkar janji) atau perbuatan melanggar hukum (onrechtmatigedaad).

Oleh karena itu, dalam sengketa konsumen bisa diajukan tuntutan ganti-rugi berdasarkan wanprestasi manakala antara pelaku usaha dan konsumen tersebut terjadi adanya hubungan kontraktual dalam transaksi konsumen.

Bentuk "ganti-rugi" atau "kerugian" yang dimaksudkan dalam UUPK itu dapat berupa :

a. Pengembalian uang; atau

b. Penggantian barang dan/atau jasa yang sejenis atau setara nilainya; atau

c. Perawatan kesehatan dan/atau pemberian santunan (pasal 19 ayat (2) UUPK).

Kemudian, gugatan juga dapat diajukan oleh sekelompok konsumen yang mempunyai kepentingan yang sama. Inilah bentuk gugatan yang dikenal dengan istilah "class action", suatu istilah yang dikenal pada common law system. Class action (diterjemahkan gugatan kelompok atau gugatan perwakilan) adalah gugatan perdata biasa yang diajukan oleh satu orang atau lebih atas nama sejumlah orang lain yang mempunyai tuntutan yang sama terhadap tergugat. Jadi gugatan kelompok ini merupakan akibat dari proses kerugian yang sama yang dialami oleh beberapa orang, misalnya produk makanan tertentu yang membahayakan kesehatan manusia, maka yang dapat menuntut ganti-rugi bukan hanya untuk mereka sendiri saja, melainkan juga untuk semua orang yang telah mengalami kerugian yang sama. Orang yang menjadi wakil itu mewakili kepentingan hukum dia/ mereka sendiri serta kepentingan anggota masyarakat yang lain.

Di Amerika Serikat, gugatan dengan cara ini berdasarkan persyaratan sebagai berikut :

1. Jumlah orang yang mengajukan gugatan sedemikian banyaknya/kelas yang diwakili harus sedemikian besar jumlahnya, sehingga apabila gugatan diajukan satu demi satu sangat tidak praktis,

2. Harus ada kesamaan fakta dan permasalahan hukum antara pihak yang mewakili dan pihak yang diwakili,

3. Tuntutan penggugat maupun pembelaan tergugat haruslah sejenis, dan

4. Mewajibkan perwakilan kelas untuk menjamin secara jujur dan adil serta mampu melindungi kepentingan pihak yang diwakili (Santoso, 1977 :11).

UUPK mengatur gugatan perwakilan/gugatan kelompok dalam pasal 46 ayat (1) mengatur : "Gugatan atas pelanggaran pelaku usaha dapat dilakukan oleh :...... sekelompok konsumen yang mempunyai kepentingan yang sama. Di dalam ayat (2)-nya diatur: "Gugatan yang diajukan sekelompok konsumen sebagaimana dimaksud pada ayat (1) huruf b, ..... diajukan kepada peradilan umum. Sedang pada penjelasan pasal tersebut dinyatakan : "UndangUndang ini mengakui gugatan kelompok atau class 
action". Lebih lanjut dinyatakan "gugatan kelompok atau class action harus diajukan oleh konsumen yang benar-benar dirugikan dan dapat dibuktikan secara hukum, salah satu diantaranya adalah adanya bukti transaksi".

Selain itu, lembaga perlindungan konsumen swadaya masyarakat (LPKSM) dapat juga mengajukan gugatan. Adapun persyaratan yang harus dipenuhi oleh LPKSM agar dapat mengajukan gugatan adalah:

1. Berbentuk badan hukum atau yayasan,

2. Anggaran dasarnya dengan tegas menyebutkan tujuan organisasi itu untuk melindungi kepentingan konsumen, dan

3. Telah melaksanakan kegiatan sesuai dengan anggaran dasarnya.

Dengan demikian, UUPK membuka kemungkinan proses beracara yang dilakukan oleh lembaga / organisasi tertentu yang memiliki legal-standing. Hak yang dimiliki lembaga/organisasi ini dikenal dengan hak gugat LSM (NGO's standing). Hal ini diatur dalam pasal 46 ayat (1) huruf $\mathrm{c}$ UUPK (Purwadi, $2001: 266$ ).

Istilah "legal standing" terkait dengan "the concept of locus standi" : ialah seseorang yang mengajukan gugatan harus mempunyai hak dan kualitas sebagai penggugat. Kata "seseorang" ini merupakan pengertian "orang dalam hukum" yang kemudian diperluas pada badan hukum. Basan hukum sebagai subyek penggugat maupun tergugat bukanlah hal yang sama sekali baru (Shofie, $2003: 92$ ).

Subyek penggugat ialah NGO atau LPKSM, yaitu organisasi non pemerintah yang bergerak di bidang perlindungan konsumen. Konsumen bukanlah subyek penggugat dalam prosedur gugatan legal standing ini, sedangkan subyek tergugat adalah pelaku usaha. Dalam definisi yang dinyatakan dalam pasal 1 angka 9 UUPK ada suatu keinginan agar LPKSM itu wajib terdaftar dan diakui oleh pemerintah. Tanpa pendaftaran dan pengakuan tersebut, LPKSM tidak dapat menyandang hak sebagai para pihak dalam proses beracara di pengadilan, terutama berkaitan dengan pencarian "legal standing" LPKSM. Secara administratif terjadi suatu konsekuensi logis yaitu pendaftaran dan pengakuan itu dapat dicabut oleh pihak yang memberikan (dalam hal ini pemerintah) manakala LPKSM telah menyimpang dari fungsi dan tujuannya (Purwadi, 2001 : 267).

UUPK juga mengatur mengenai gugatan atas pelanggaran pelaku usaha dapat diajukan oleh pemerintah dan/atau instansi terkait ke peradilan umum (pasal 46 ayat (1) huruf d dan pasal 46 ayat (2) UUPK). Gugatan yang diajukan oleh pemerintah ini bisa dilakukan apabila produk yang dikonsumsi atau dimanfaatkan mengakibatkan kerugian materi yang besar dan/atau korban yang tidak sedikit. Selanjutnya pada penjelasan pasal tersebut, menyatakan besar dampaknya terhadap konsumen (baca : dampak konsumsi dan/atau pemanfaatan barang dan/atau jasa) 
merupakan tolok ukur kerugian materi yang besar dan/atau korban yang tidak sedikit. Misalnya, kasus korban massal keracunan mie instan, barangkali pemerintah merasa dirugikan karena pemerintah juga akan ikut penanggulangan korban untuk dibawa ke rumah sakit, mengerahkan tenaga medis, memulihkan kondisi sosial-ekonomi masyarakat yang terkena musibah bahkan meredakan ketegangan dan kepanikan masyarakat akibat musibah tersebut; semuanya itu membutuhkan tenaga dan biaya yang tidak sedikit dikeluarkan oleh pemerintah (Purwadi. $2001: 267)$.

Contoh konkrit pada bulan Juni 1994, korban berjatuhan di Palembang, Jambi dan beberapa tempat, akibat memakan mie instant 28 orang dirawat di rumah sakit dan 5 orang lainnya meninggal dunia. Kemudian terjadi lagi dengan kesalahan dibebankan kepada konsumen karena menggunakan air dan alat yang digunakan memasak tercemar dan pada bulan Juni 1994 pun, produsen mie instant ternyata menarik produknya di lapangan (Shofie, $2003: 109$ ).

Mestinya kasus semacam ini, yang menjadi perhatian publik, layak untuk menjadi pertimbangan bagi pemerintah dan/atau instansi terkait untuk proaktif mengupayakan penyelesaiannya bahkan bila perlu mengajukan gugatan kepada pelaku usahanya. Sikap proaktif ini dilakukan sebagai salah satu upaya mendorong :

a. Pendidikan konsumen bagi pelaku usaha dan konsumen melalui penegakan hukum secara sistematis,

b. Dihormatinya norma-norma perlindungan konsumen melalui langkah alternatif lain (gugatan perdata oleh pemerintah dan/atau instansi lainnya, ketika sistem peradilan pidana digunakan dengan pendekatan ultimum remedium, bukan premium remedium (Shofie, 2003 : 107).

Pada dasarnya, apabila terjadi sengketa konsumen maka langkah awal yang harus ditempuh menurut UUPK adalah upaya penyelesaian sengketa konsumen secara sukarela. Upaya penyelesaian ini berpangkal tolak dari prinsip product liability (tanggung gugat produk). Pasal 19 ayat (1) UUPK secara lebih tegas merumuskan tanggung gugat produk, dengan menyatakan : "Pelaku usaha bertanggungjawab memberikan ganti rugi atas kerusakan, pencemaran dan/atau kerugian konsumen akibat mengkonsumsi barang dan/atau jasa yang dihasilkan atau diperdagangkan" (Shidarta, 2000 : 66). Selanjutnya, ganti-rugi yang diberikan berupa pengembalian uang atau penggantian produk yang sejenis atau perawatan kesehatan dan/atau pemberian santunan. Pemberian ganti-rugi dilaksanakan dalam tenggang waktu 7 hari setelah tanggal transaksi.

Penyelesaian sengketa konsumen secara sukarela dengan menggunakan pasal 19 UUPK ini, dimungkinkan pelaku usaha menolak, atau tidak memberikan tanggapan, atau bahkan tidak memenuhi pemberian ganti-rugi. Pemberian ganti-rugi tersebut 
merupakan menifestasi pertanggungjawaban perdata terhadap pelaku usaha, dan ini harus dipisahkan dari pertanggungjawaban pidana. Oleh karena itu, pemberian ganti-rugi tidak menghapuskan kemungkinan diajukannya suatu tuntutan pidana berdasarkan pembuktian lebih lanjut mengenai adanya unsur kesalahan \{lihat pasal 19 ayat (4) UUPK \}.

Dengan demikian, dapat memberikan kesempatan kepada konsumen untuk mengajukan gugatan kepada BPSK atau mengajukan ke peradilan umum. Penyelesaian sengketa konsumen melalui BPSK dilakukan untuk mencapai kesepakatan mengenai bentuk dan besarnya ganti-rugi dan/atau mengenai tindakan tertentu untuk menjamin tidak akan terjadi kembali atau tidak terulang kembali kerugian yang diderita oleh konsumen. Putusan BPSK dilakukan dalam bentuk majelis dan putusan bersifat final dan mengikat. Yang dimaksud dengan bersifat "final", ialah atas putusan BPSK tersebut tidak ada upaya banding dan kasasi (penjelasan pasal 54 ayat (3) UUPK). Untuk dapat dilaksanakan putusan BPSK tersebut dimintakan penetapan eksekusinya kepada pengadilan negeri di tempat konsumen yang dirugikan (pasal 57 UUPK).

Meskipun putusan BPSK dikatakan final, ternyata UUPK membuka peluang kepada para pihak yang bersengketa untuk mengajukan keberatan atas putusan BPSK tersebut ke pengadilan negeri. Dan untuk selanjutnya, apabila pihak yang bersengketa menyatakan keberatan atas pengadilan negeri juga diberikan kesempatan untuk mengajukan kasasi ke Mahkamah Agung. Memang, kalau putusan BPSK tersebut dinyatakan final itu dimaksudkan putusan BPSK tersebut tidak dapat dimintakan banding dan kasasi, tentu putusan BPSK tersebut tidak bisa langsung dimintakan pemeriksaan di pengadilan tinggi sebagai peradilan banding, maupun pemeriksaan di Mahkamah Agung sebagai peradilan kasasi. Akan tetapi, para pihak yang bersengketa diberi kesempatan untuk di pengadilan negeri, dan bisa diteruskan pada pemeriksaan keberatan di Mahkamah Agung.

Sebenarnya, kalau penyelesaian sengketa konsumen yang dilakukan oleh BPSK tersebut berdasarkan wewenang yang ada, dilaksanakan dengan cara melalui konsiliasi, atau mediasi, atau arbitrase, maka sudah menutup kemungkinan untuk dilakukan pemeriksaan secara litigasi. Salah satu akibat hukum apabila suatu sengketa oleh para pihak yang bersengketa dimintakan upaya penyelesaian sengketa alternatif (Alternative Dispute Resolution) maka akan meniadakan para pihak untuk menggunakan penyelesaian sengketa secara litigasi (melalui badan peradilan) (Purwadi, $2001: 269$ ).

\section{Upaya Penyelesaian Sengketa Alternatif (ADR) Pada Sengketa Konsumen}

Bentuk tuntutan hak berupa ganti-rugi dalam sengketa konsumen dapat menandakan bahwa sengketa konsumen termasuk dalam kategori 
sengketa perdata.

Sebenarnya terdapat dua alternatif forum penyelesaian sengketa perdata, yaitu : Pertama, penyelesaian sengketa perdata yang dilakukan melalui lembaga peradilan (by court dispute settlement). Penyelesaian sengketa perdata melalui lembaga peradilan telah lazim dipraktekkan selama ini. Selama ini penyelesaian setiap sengketa perdata senantiasa dilakukan melalui lembaga peradilan dengan menggunakan ketentuan substansial dan ketentuan prosedural yang telah ditetapkan dalam sejumlah peraturan perundang-undangan. Kedua, penyelesaian sengketa perdata dilakukan diluar lembaga peradilan (out of court dispute settlement), antara lain melalui negosiasi, konsiliasi, mediasi, dan arbitrase.

Penyelesaian sengketa perdata dilakukan di luar pengadilan dengan berbasiskan pada kesepakatan dan kesukarelaan para pihak yang bersengketa(Wibowo, 2001 : 552). Pengertian istilah "ADR" adalah pranata penyelesaian sengketa atau beda pendapat melalui prosedur yang disepakati para pihak, yaitu penyelesaian sengketa atau beda pendapat di luar pengadilan dengan cara konsultasi, negosiasi, mediasi, konsiliasi, atau penilaian ahli. Jadi ADR ini suatu pranata penyelesaian sengketa di luar pengadilan berdasarkan kesepakatan para pihak dengan mengesampingkan penyelesaian sengketa secara litigasi di pengadilan. Sengketa atau beda pendapat yang dapat diselesaikan oleh para pihak melalui ADR hanya sengketa atau beda pendapat di bidang perdata (Usman; $2003: 7$ ).

Proses penyelesaian sengketa atau beda pendapat dengan melalui cara-cara ADR dapat dianggap sebagai proses penyelesaian sengketa yang berbudaya. Betapa kita sadari bahwa budaya masyarakat Indonesia menjunjung tinggi proses penyelesaian berdasarkan konsensus. Proses penyelesaian tersebut bukanlah sesuatu yang baru bagi masyarakat Indonesia dengan nilai-nilai budayanya yang berjiwa kooperatif (Margono, $2000: 38$ ).

Sebenarnya ADR bisa diartikan sebagai :

1. Alternative to litigation, yaitu seluruh mekanisme penyelesaian sengketa di luar pengadilan, termasuk arbitrase, merupakan bagian dari ADR.

2. Alternative to adjudication, yaitu di luar litigasi dan arbitrase merupakan bagian dari ADR, yang meliputi mekanisme penyelesaian sengketa yang bersifat konsensus atau kooperatif, seperti negosiasi, mediasi, dan konsiliasi.

Dengan demikian, dapat diklasifikasikan proses penyelesaian sengketa itu, meliputi :

I. Proses adjudikasi, meliputi :

1. Litigasi

2. Arbitrase

II. Proses konsensus, meliputi :

1. Negosiasi

2. Mediasi

3. Konsiliasi

Proses adjudikasi menandakan sebagai suatu proses 
penyelesaian sengketa yang melibatkan pihak ketiga yang mempunyai kekuatan untuk memutuskan.

Sedangkan untuk membedakan, maka litigasi merupakan adjudikasi publik, sedangkan arbitrase merupakan adjudikasi privat. Adjudikasi publik, yaitu melalui court and administrative proceedings, akan menghasilkan standar prosedur yang adil, memberi peluang yang luas kepada para pihak untuk didengar keterangannya, menyelesaikan sengketa, serta menjaga ketertiban umum (Margono, $2000: 24$ ).

Dibandingkan dengan adjudikasi publik, maka arbitrase sebagai salah satu bentuk adjudikasi privat lebih memberikan kebebasan, pilihan, otonomi, dan kerahasiaan kepada para pihak yang bersengketa (Margono, 2000:25).

Proses konsensus didasarkan pada "perundingan" untuk mencapai kesepakatan penyelesaian sengketa di antara kedua belah yang bersengketa. Proses konsensus yang merupakan "keseharian" adalah negosiasi, artinya setiap orang melakukan negosiasi dalam kehidupan sehari-hari. Negosiasi ini merupakan komunikasi dua arah yang dirancang untuk mencapai kesepakatan pada saat kedua belah pihak memiliki berbagai kepentingan yang sama maupun yang berbeda (Margono, 2000 : 49).

Dengan demikian, dapat dikatakan bahwa negosiasi itu merupakan cara penyelesaian sengketa di luar pengadilan oleh para pihak yang bersengketa atau kuasanya secara langsung pada saat persidangan dilakukan, tanpa keterlibatan pihak ketiga yang bertindak sebagai penengah. Para pihak yang bersengketa yang secara langsung melakukan persidangan (tawar-menawar), sehingga menghasilkan suatu kesepakatan bersama. Pada umumnya kesepakatan bersama tersebut dituangkan secara tertulis (Usman, 2003 : 55).

Menurut Christopher W. Moore, "negotiation is a form of joint problem solving". Topik masalah yang menjadi sasaran negosiator seringkali disebut issues. Persoalan itu ada karena para pihak tidak sependapat dalam topik tertentu dan karena mereka merasakan adanya kebutuhan-kebutuhan dan kepentingan-kepentingan yang eksklusif (Moore, 2003: 72).

Kalau kemudian, proses konsensus yang dilakukan melalui perundingan itu melibatkan pihak ketiga, yang bertindak sebagai penengah, maka proses itu mengarah pada cara penyelesaian sengketa melalui cara mediasi atau cara konsiliasi. Apabila pihak yang bersengketa tidak mampu merumuskan suatu kesepakatan dan pihak ketiga mengajukan usulan jalan keluar dari sengketa, proses ini disebut konsiliasi. Hal ini yang menyebabkan istilah konsiliasi kadang sering diartikan dengan mediasi. Seperti halnya dalam mediasi, maka konsiliasi juga merupakan suatu proses penyelesaian sengketa diantara para pihak dengan melibatkan pihak ketiga yang netral dan tidak memihak. Hanya saja peran yang dimainkan oleh seorang mediator dengan konsiliator berbeda. Seperti 
mediator, tugas konsiliator hanya sebagai pihak fasilitator untuk melakukan komunikasi di antara pihak sehingga dapat diketemukan solusi oleh para pihak sendiri. Konsiliator hanya melakukan tindakantindakan seperti mengatur waktu dan tempat pertemuan para pihak, mengarahkan subyek pembicaraan, membawa pesan dari satu pihak kepada pihak lain jika pesan tersebut tidak mungkin disampaikan langsung atau tidak mau bertemu muka langsung dan lain-lain.

Sedangkan seorang mediator juga melakukan hal-hal yang dilakukan oleh konsiliator, tetapi juga melakukan lebih jauh dari itu, sebab mediator dapat menyarankan jalan keluar atau proposal penyelesaian sengketa. Meskipun mediator berwenang untuk mengusulkan solusi penyelesaian sengketa, akan tetap baik mediator maupun konsiliator tidak berwenang memutus perkara. Hal ini berbeda dengan arbitator yang menyelesaikan sengketa melalui arbitrase.

Dengan demikian, mediasi adalah proses perundingan (atau juga dapat dikatakan proses negosiasi) pemecahan sengketa, dimana pihak luar yang tidak memihak bekerjasama dengan pihak yang bersengketa untuk membantu memperoleh kesepakatan penyelesaian sengketa dengan memuaskan. Berbeda dengan hakim atau arbitator, maka mediator tidak mempunyai wewenang untuk memutuskan sengketa. Mediator hanya membantu para pihak untuk menyelesaikan persoalan-persoalan yang dikuasakan kepadanya (Margono, 2000:28).
Menurut Christopher W. Moore "Mediation is generally defined as the intervention in a negotiation or a conflict of an acceptable third party who has limited or no authoritative decision making power, who assists the involved parties to voluntarily reach a mutually acceptable settlement of the issues in dispute" (Moore, 2003:15).

"Acceptability" dimaksudkan bahwa para pihak yang bersengketa mempunyai kehendak untuk membolehkan pihak ketiga untuk masuk dalam sengketa dan membantu mereka dalam mencapai penyelesaian. Ini berarti para pihak menyetujui kehadiran mediator dan ada kehendak untuk mendengarkan dan mempertimbangkan dengan sungguh-sungguh saran/usul bagaimana untuk mengurus dan memecahkan persengketaan mereka (Moore, 2003 : 16).

Bentuk penyelesaian sengketa melalui arbitrase saat ini seringkali dilakukan oleh pelaku usaha untuk sarana penyelesaian sengketa bisnis. Menurut Black's Law Dictionary yang dimaksud dengan arbitration adalah: "a method of dispute resolution involving one or more neutral third parties who are agreed to by the disputing parties and whose decision is binding ..." (Garner, 1999 : $100)$.

Adapun menurut Kamus Hukum Ekonomi ELIPS, yang dimaksud dengan arbitration (arbitrase, perwasitan) adalah "metode penyelesaian sengketa di luar pengadilan dengan memakai jasa wasit atas 
persetujuan para pihak yang bersengketa dan keputusan wasit mempunyai kekuatan hukum mengikat" (Pakpahan, 1997 : 8). Sedangkan hukum positif arbitrase yang terbaru, yaitu dalam ketentuan pasal 1 Undang-Undang Nomor 30 Tahun 1999 tentang Arbitrase dan Alternatif Penyelesaian Sengketa ditegaskan bahwa yang dimaksud dengan arbitrase adalah "cara penyelesaian suatu sengketa perdata di luar peradilan umum yang didasarkan pada perjanjian arbitrase yang dibuat para pihak yang bersengketa".

Arbitrase merupakan bentuk atau forum penyelesaian sengketa di luar pengadilan yang ditentukan berdasarkan kesepakatan para pihak. Arbitrase juga merupakan forum penyelesaian sengketa perdata yang memiliki karakter menyerupai proses peradilan. Antara lain : memiliki prosedur (acara) tertentu, adanya arbitrator atau majelis arbitrator yang memiliki wewenang memutus sengketa, serta putusannya bersifat final and binding, serta dimungkinkan untuk dijalankan secara paksa (eksekusi).

UUPK menegaskan bahwa berdasarkan pilihan sukarela, maka penyelesaian sengketa konsumen dapat memilih apakah ditempuh melalui pengadilan ataukah ditempuh luar pengadilan (pasal 45 ayat (2) UUPK). Sedangkan penyelesaian sengketa konsumen di luar pengadilan diselenggarakan untuk mencapai kesepakatan mengenai bentuk dan besarnya ganti rugi dan/atau mengenai tindakan tertentu untuk menjamin tidak akan terjadi kembali atau tidak akan terulang kembali kerugian yang diderita oleh konsumen (pasal 47 UUPK). Proses penyelesaian sengketa ini menupakan proses "out of court dispute settlement", melalui negoisasi. Dalam proses penyelesaian sengketa konsumen melalui negoisasi ini menyampingkan penyelesaian secara litigasi di pengadilan, sehingga diselesaikan melalui pertemuan langsung antara pelaku usaha dan konsumen untuk mencapai kesepakatan penyelesaian sengketa di antara kedua belah pihak.

Namun, melalui instrumen hukum administrasi berdasarkan UUPK, penyelesaian sengketa konsumen di luar pengadilan difasilitasi oleh pemerintah dengan membentuk BPSK. Majelis BPSK mempunyai kewajiban menjaga ketertiban jalannya persidangan (pasal 27 ayat (2) Keputusan Menperindag Nomor 350/MPP/Kep/12/ 2001). Terdapat tiga tata cara persidangan di BPSK (lihat pasal 54 ayat (4) UUPK jo pasal 28 sampai dengan pasal 36 Keputusan Menperindag Nomor 350/MPP/ Kep/12/2001), yaitu :

1. Persidangan dengan cara konsiliasi;

2. Persidangan dengan cara mediasi;

3. Persidangan dengan cara arbitrase.

Sedangkan penyelesaian sengketa konsumen oleh BPSK melalui cara konsiliasi, atau mediasi atau arbitrase dilakukan atas dasar pilihan dan persetujuan para pihak yang bersangkutan. Dalam Keputusan Menperindag ini juga dinyatakan apa yang dimaksud 
dengan :

1. Konsiliasi adalah proses penyelesaian sengketa konsumen di luar pengadilan dengan perantaraan BPSK untuk mempertemukan para pihak yang bersengketa dan penyelesaiannya diserahkan kepada para pihak;

2. Mediasi adalah proses penyelesaian sengketa konsumen di luar pengadilan dengan perantaraan BPSK sebagai penasihat dan penyelesaiannya diserahkan kepada para pihak;

3. Arbitrase adalah proses penyelesaian sengketa konsumen di luar pengadilan yang dalam hal ini para pihak yang bersengketa menyerahkan sepenuhnya penyelesaian sengketa kepada BPSK.

Bagaimanakah sebenarnya prinsip-prinsip persidangan BPSK dengan cara konsiliasi, dengan cara mediasi, serta dengan cara arbitrase?

1. Persidangan dengan cara konsiliasi

Inisiatif salah satu pihak atau para pihak membawa sengketa konsumen ke BPSK, ditangani Majelis BPSK yang bersikap pasif, yang bertindak sebagai pemerantara atau konsiliator antara para pihak yang bersengketa mempunyai tugas :

a. Memanggil konsumen dan pelaku usahayang bersengketa;

b. Memanggil saksi dan saksi ahli bila diperlukan;

c. Menyediakan forum bagi konsumen dan pelaku usaha yang bersengketa; d. Menjawab pertanyaan konsumen dan pelaku usaha perihal peraturan perundang-undangan di bidang perlindungan konsumen.

Prinsip tata cara penyelesaian sengketa konsumen dengan cara konsiliasi ada 2 (dua) yaitu : Pertama, proses penyelesaian sengketa konsumen menyangkut bentuk maupun jumlah ganti rugi diserahkan sepenuhnya kepada pihak, sedangkan Majelis BPSK bertindak pasif sebagai konsiliater; Kedua, hasil musyawarah konsumen dan pelaku usaha dikeluarkan dalam bentuk keputusan BPSK

2. Persidangan dengan cara mediasi.

Seperti halnya dengan cara konsiliasi, cara mediasi ditempuh atas inisiatif salah satu pihak atau para pihak, sedangkan Majelis BPSK bersikap aktif, karena bertindak sebagai mediator dengan tugas :

a. Memanggil konsumen dan pelaku usaha yang bersengketa;

b. Memanggil saksi dan saksi ahli bila diperlukan;

c. Menyediakan forum bagi konsumen dan pelaku usaha yang bersengketa:

d. Secara aktif mendamaikan konsumen dan pelaku usaha yang bersengketa;

e. Secara aktif memberikan saran atau anjuran penyelesaian sengketa konsumen sesuai dengan peraturan perundang--undangan di bidang perlindungan konsumen.

Prinsip tata cara penyelesaian sengketa konsumen dengan cara mediasi ada 2 (dua), yaitu: Pertama, 
proses penyelesaian sengketa konsumen menyangkut bentuk maupun jumlah ganti rugi diserahkan sepenuhnya kepada para pihak. sedangkan Majelis BPSK bertindak aktif sebagai mediator dengan memberikan nasehat, petunjuk, saran, dan upaya-upaya lain dalam menyelesaikan sengketa; Kedua, hasil musyawarah konsumen dan pelaku usaha dikeluarkan dalam bentuk keputusan BPSK.

\section{Persidangan dengan cara arbitrase.}

Cara ini, para pihak menyerahkan sepenuhnya kepada Majelis BPSK untuk memutuskan dan menyelesaikan sengketa konsumen. Proses pemilihan Majelis BPSK sebagai arbitor ditempuh melalui 2 (dua) tahap, yaitu : Pertama, para pihak memilih arbitor dari anggota BPSK yang berasal dari unsur pelaku usaha dan konsumen sebagai anggota Majelis BPSK; Kedua, arbitor yang dipilih para pihak tersebut kemudian memilih arbitor ketiga dari anggota BPSK, dari unsur pemerintah sebagai Ketua Majelis BPSK.

Undang-Undang Nomor 30 Tahun 1999, pada pasal 7-nya mengatur bahwa para pihak dapat menyetujui suatu sengketa yang terjadi atau yang akan terjadi antara mereka untuk diselesaikan melalui arbitrase. Kewenangan arbitrase timbul dengan adanya kesepakatan berupa perjanjian arbitrase yang dibuat dan ditanda tangani oleh para pihak sebelum maupun sesudah terjadinya sengketa. Kesepakatan berupa kesepakatan kehendak untuk menyelesaikan sengketa melalui arbitrase dituangkan dalam perjanjian arbitrase tersendiri (terpisah dari perjanjian pokoknya) maupun dibuat dalam satu kesatuan dengan perjanjian pokoknya. Perjanjian arbitrase dapat dibuat sebelum terjadinya sengketa (pactum de compomittendo) maupun sesudah sengketa terjadi (acta van compromise).

Dengan adanya perjanjian arbitrase, maka para pihak secara yuridis terikat pada isi perjanjian tersebut (pacta sunt servanda), artinya sengketa yang terjadi atau akan terjadi di antara mereka harus diselesaikan melalui arbitrase. Menurut pasal 11 Undang--Undang Nomor 30 Tahun 1999 adanya perjanjian arbitrase telah meniadakan hak para pihak untuk mengajukan sengketa tersebut diajukan ke pengadilan negeri. Bila mana sengketa tersebut tetap diajukan ke pengadilan negeri, maka pengadilan negeri secara ex of ficio wajib menolak mengadili dengan menyatakan bahwa dirinya tidak berwenang secara absolut untuk mengadili sengketa.

Menurut ketentuan pasal 60 Undang-Undang Nomor 30 Tahun 1999, putusan arbitrase bersifat final dan mempunyai kekuatan hukum tetap dan mengikat para pihak, sehingga terhadap putusan tersebut tidak dapat diajukan upaya hukum banding, kasasi atau peninjauan kembali sebagaimana yang terjadi dalam proses peradilan. Jadi seyogyanya putusan arbitrase dapat dipenuhi secara sukarela oleh para pihak yang bersengketa. Hal yang menjadi 
pertimbangan bahwa penyelesaian sengketa melalui arbitrase maupun pemilihan arbitomya dilakukan oleh para pihak berdasarkan kesepakatan bersama, sehingga wajar kalau mereka bersedia menerima segala konsekuensi yang timbul dari proses arbitrase, termasuk apapun bunyi putusannya. Terkecuali apabila pada proses arbitrase tersebut terjadi penyimpangan prosedural sehingga merugikan pihak yang bersengketa.

Dalam kaitannya hubungan hukum yang dilakukan antara pelaku usaha dan konsumen itu dituangkan dalam suatu perjanjian (baku) ada kemungkinan dilakukan "choice of forum" dengan memilih arbitrase sebagai forum penyelesaian sengketa yang mungkin akan timbul dikemudian hari.

Dengan demikian, adanya pactum de compomittendo, sehingga pihak pelaku usaha dan konsumen terikat dengan klausula arbitrase, sehingga tertutup kemungkinan diselesaikan melalui proses peradilan. Kalau hal ini terjadi, maka putusan arbitrase akan mempunyai kekuatan final and binding, sehingga tidak bisa dimintakan upaya hukum banding dan kasasi. Kalau dalam proses arbitrase dikehendaki campur tangan BPSK melalui persidangan dengan cara arbitrase tergantung dari kesepakatan para pihak bersengketa. Oleh karena itu, memberi kesempatan bagi pelaku usaha dan konsumen yang bersengketa untuk memilih arbitrase dengan 2 macam arbitrase, yaitu:

1. Penyelesaian arbitrase berdasarkan UUPK (arbitrase institusional).

2. Penyelesaian arbitrase berdasarkan UndangUndang Nomor 30 Tahun 1999 (arbitrase institusional atau arbitrase ad-hoc).

\section{PENUTUP}

Sebenarnya proses penyelesaian sengketa konsumen diawali dengan cara negosiasi, sehingga terjadi proses perundingan untuk mencapai kesepakatan antara pelaku usaha dan konsumen menyangkut bentuk dan jumlah ganti rugi. Memang, dalam proses ini bisa menghasilkan kemungkinankemungkinan yaitu berhasil mencapai kesepakatan atau pelaku usaha menolak/atau tidak memberikan tanggapan/bahkan tidak memenuhi pemberian ganti rugi. Penyelesaian sengketa konsumen tersebut hanya berkaitan dengan aspek pertanggungjawaban perdata.

Apabila proses penyelesaian sengketa konsumen dengan cara negosiasi lazimnya disebut penyelesaian sengketa secara sukarela -tidak berhasil, maka bisa dilakukan dengan mengajukan penyelesaian di luar pengadilan maupun di pengadilan. Penyelesaian di luar pengadilan dimungkinkan dengan menggunakan forum BPSK dan juga bisa dilakukan melalui arbitrase manakala dalam perjanjian antara pelaku usaha dan konsumen terdapat klausula arbitrase. BPSK dalam menyelesaikan sengketa konsumen dapat dilakukan dengan cara-cara konsiliasi, mediasi maupun arbitrase. 


\section{DAFTAR PUSTAKA}

\section{A. Buku}

Margono, Suyud, ADR (Alternative Dispute Resolution) \& Arbitrase (Proses Pelembagaan dan Aspek Hukum); Ghalia Indonesia, Jakarta, 2000.

Moore, Christopher, The Mediation Proses, JosseyBoss, San Francisco, 2003.

Nasution, Az,, Konsumen Dan Hukum, Pustaka Sinar Harapan, Jakarta, 2000.

Rahardjo, Satjipto, llmu Hukum, Citra Aditya Bakti, Bandung, 2000.

Santoso, Mas Achmad, Konsep Dan Penerapan Gugatan Perwakilan (Class Actions), ICEL, Jakarta, 1997.

Shofie, Yusuf, Penyelesaian Sengketa Konsumen Menurut UUPK, Citra Aditya Bakti, Bandung, 2003.

Sidharta, Hukum Perlindungan Konsumen Indonesia, Grasindo, Jakarta, 2000.

Usman, Rachmadi, Pilihan Penyelesaian Sengketa Di Luar Pengadilan, Citra Aditya Bakti, Bandung. 2003.

\section{B. Jurnal/Kamus}

Purwadi, Ari, "Model Penyelesaian Sengketa Konsumen Di Indonesia", Jurnal Yustika, Vol. 4 No. 2 Desember 2001.

Wibowo, Basuki Rekso, "Prinsip-prinsip Dasar Arbitrase Sebagai Alternatif Penyelesaian Sengketa Dagang Di Indonesia", Yuridika, Vol. 6 No. 6 Nopember 2001.
Bryan A. Garner, ed. In chief, Black Law Dictionary, Seventh Edition, West Group-St. Paul, Minn., 1999.

Pakpahan, Normin S., Ketua Tim Penyunting, Kamus Hukum Ekonomi ELIPS, Edisi Pertama, Proyek ELIPS, Jakarta, 1997.

C. Peraturan Perundang-Undangan

Undang-Undang Nomor 8 Tahun 1999 Tentang Perlindungan Konsumen.

Undang-Undang Nomor 30 Tahun 1999 Tentang Arbitrase dan Alternatif Penyelesaian Sengketa.

Keputusan Menteri Perindustrian dan Perdagangan Nomor 350/MPP/Kep/12/2001 Tentang Pelaksanaan Tugas dan Wewenang Badan Penyelesaian Sengketa Konsumen (BPSK). 